\title{
Calculating China's Historical Economic Aggregate: A GDP-centered Overview*
}

$\mathrm{Ni}$ Yuping, ${ }^{\mathrm{a}} \mathrm{Xu} \mathrm{Yi}{ }^{\mathrm{b}}$ and Bas van Leeuwen ${ }^{\mathrm{c}}$

${ }^{a}$ School of Humanities, Tsinghua University

${ }^{b}$ College of Historical Culture and Tourism, Guangxi Normal University

${ }^{c}$ International Institute of Social History, the Netherlands

经过中外学者的共同努力, 自 20 世纪 30 年代以来兴起的中国历史 GDP 研究, 在 1990 年以后引发全 球关注。有关中国历史 GDP 的研究被推到国际经济史学界的最前沿, 成为引领国际经济史学界研究的热 点问题。与此同时, 国内外学者也开始进行理性反思和理论探讨。估算方法的多元化、历史数据的系统重 建与国际比较成为今后中国 “历史 GDP 研究” 的三大发展趋向, 通过推动与引领这三大发展趋向, 中国 学者在国际经济史学界必将发挥越来越重要的作用。

\section{关键词: 中国 历史 GDP 经济总量 估算}

Since the 1990s, thanks to the concerted efforts of domestic and international scholars, the research on China's historical GDP that began in the 1930s has received widespread attention, and is becoming a widely discussed issue at the forefront of research on world economic history. At the same time, several scholars at home and abroad have also voiced a call for more theoretical and empirical reflection within this line of research. Diversification of methods, systematic reconstruction of historical data, and international comparisons represent three emerging trends in future research on this subject. By encouraging and leading these trends, Chinese scholars can assume a greater role in international research on economic history.

Keywords: China, historical GDP, economic aggregate, calculation

As one of the four ancient civilizations, China was once the largest economy in the world. Since the late $20^{\text {th }}$ century, and particularly since the advent of the new century, the Chinese economy has risen so rapidly under reform and opening up that it has overtaken Japan and now is second only to America in terms of GDP; that is, it is the world's second largest economy. It is against this backdrop that the reassessment of China's historical level of economic development and its position in world economic history is arousing increasing attention in China and across the world. At the same time, with the emergence of quantitative history, new economic history and other disciplines, historical research on GDP $^{1}$ that aims to quantify China's level of economic development through history in relation to other world economies has assumed increasing importance, constituting one of the most vibrant research areas and involving scholars from a variety of disciplines and nations. Moreover, the trend has sparked extensive and continuing international discussion of such issues as the "Great Divergence." Today, as Chinese academics are becoming increasingly globalized, the trajectory of China's historical GDP research showcases the internationalization of Chinese scholarship. It thus appears particularly

\footnotetext{
* We greatly appreciate the comments and suggestions on this article made by Hao Zhiqing, Shi Zhihong and other anonymous reviewers.

The research leading to these results received funding from the European Research Council under the European Union's Horizon 2020 Programme / ERC-StG 637695 - HinDI, as part of the project "The historical dynamics of industrialization in Northwestern Europe and China ca. 1800-2010: a regional interpretation".

1 To date, much of the research on China's historical GDP focuses on the period from the Tang and Song dynasties to the founding of New China in 1949. Systematic study of pre-Tang historical GDP is rather difficult due to the lack of sources, and GDP data since the founding of New China is accessible through modern statistical methods. Therefore, "research on China's historical GDP" in this study refers to the calculation of GDP by economic historians spanning the period from the Tang and Song dynasties to the Republic of China.
} 
important that we track this globally significant trend. In this study, we will trace the dramatic rise of research on China's historical GDP across different academic disciplines and countries, and will, in so doing, summarize some of the emerging problems and trends.

\section{Origins and Preliminary Exploration: 1930-1990}

Approaching a country or region's economic aggregate from a macro-perspective, and comparing it with international experience, has a fairly long history. As early as the $17^{\text {th }}$ century, William Petty, a classical British political economist, attempted at a qualitative estimate of the national economies of England and Wales and used his "political arithmetic" to compare Britain, the Netherlands and France. ${ }^{2}$ However, Petty's measurement was too crude to evolve into a specialized system on its own. It was not until the 1930s that the concepts of GDP and national income were proposed, defined and standardized by the American economists Clark Warburton, Simon Kuznets and others to address Depression-era issues, giving rise to the statistical tool of what is now called GDP. ${ }^{3}$ There were two main goals in applying this new macro-statistical method to the study of long-term economic growth: to reveal the source of modern economic growth by measuring the long-term growth of per capita GDP in different countries, and to examine the East-West gap in economic development through a comparison of the emergence of modern economic growth as seen in per capita GDP. It was against this background that the pioneers of historical GDP research attempted to develop a sustained cross-country research paradigm.

The earliest endeavor was made by the British economic statistician Colin Clark, who, in 1940, calculated the national incomes of 28 countries. In his work, Clark employed income data to estimate China's GDP for the period 1925-1934. ${ }^{4}$ This is widely believed to be the earliest estimation of China's historical GDP by a Western scholar. Previously, in 1937, the Chinese economist Liu Ta-chun had released the results of the first national industry census, A Report on Chinese Industries, ${ }^{5}$ which became the main data source for research on China's industrial output in the 1930s. In 1946, Liu's monograph China's National Income, 1931-36, ${ }^{6}$ was published by the Brookings Institution, representing a ground-breaking achievement for Chinese scholars in the field. The next year, the Zhonghua Book Company in Shanghai published Wu Pao-san et al.'s China's National Income, 1933, which gave a fine-tuned estimation and assessment of China's national income in 1933. Later, on that basis, Wu extended the time period to estimate China's national income to 1929, 1936 and $1946 .^{7}$ As can be seen, Chinese research on historical GDP started almost simultaneously with the global trend.

In introducing the modern system of GDP research, these scholars opened up a new field that, in

2 William Petty, "Verbum Sapient," in Charles Henry Hull, eds., The Economic Writings of Sir William Petty, Together with the Observations upon Bills of Mortality, More Probably by Captain John Graunt, Cambridge: Cambridge University Press, 1899, vol. 1, pp. 99-120.

3 Clark Warburton, "Value of the Gross National Product and Its Components, 1919-1929," Journal of the American Statistical Association, December 1934, pp. 383-388.

4 Colin Clark: The Conditions of Economic Progress, London: Macmillan Press, 1940, p. 41.

5 Liu Dajun, A Report on Chinese Industries, Shanghai: Institute of Economic Statistics, 1937.

6 Liu Ta-chung, China's National Income, 1931-1936: An Exploratory Study, Washington: Brookings Institution, 1946.

7 In his 1948 doctoral dissertation at Harvard University, "China's Capital Formation and the Expenditure of Consumers" (pp. 204-211), Wu summarized the materials employed in China's National Income, 1933 (Shanghai: Zhonghua Book Company, 1947). Also see Wu Pao-san, “China's National Income: 1933, 1936 and 1946” (中国 国民所得：1933、1936 and 1946), Journal of Social Sciences (社会科学杂志), vol. 9, 1947, no. 2. These works were subsequently compiled and reprinted by the Commercial Press. See Wu Pao-san, China's National Income, 1933 (Beijing: The Commercial Press, 1992). 
order to quantify China's economic development level comprehensively in different historical periods, needed to transcended the boundaries of a single academic field. Initial explorations of this emerging field provided two thought-provoking questions for latecomers. Firstly, there was a fundamental consensus that, measured in per capita GDP and seen in the light of global developments, modern economic growth originated in late $18^{\text {th }}$ century Britain as attested by the success of the Industrial Revolution. Until then, it was argued, the world economy as a whole had been stuck in a Malthusian trap. Secondly, Western scholars attempting to establish long-term GDP time series across the world believed that prior to modern economic growth, the developed West had far surpassed the majority of developing countries in Asia and Africa in terms of per capita GDP. Nevertheless, their arguments still lacked support from the relevant data on modern China. China's economic development level as compared with that of the developed West before the Industrial Revolution thus became an open and unsettled issue.

From the 1950s, a growing number of historians and economists began to join the field. The main scholars taking up the first question included Chang Chung-li, Albert Feuerwerker, Liu Ta-chung, Yeh Kung-chia and Dwight Perkins. In 1962, Chang Chung-li, an economic historian who had studied in the United States, calculated China's national income during the 1880s in The Income of the Gentry, arguing that in the 1880s China's rural industry and a large part of its non-rural industry were still in the pre-modern stage of development. He compared his result with Wu Pao-san and his colleagues' estimate for 1933, and concluded that in terms of 1933 prices, when industrialization was under way in some areas, China's national income had grown by $40 \%$ and its national income per capita by $30 \%$ compared to the 1880s. ${ }^{8}$ This result was questioned by Albert Feuerwerker, an American historian of China, who believed that Chang had exaggerated the income of Chinese gentry and relied too heavily on official documents on cultivated land in $1887 .{ }^{9}$ Feuerwerker increased the estimate for rural industry by $30 \%$, which considerably reduced the growth of the Chinese economy over the period 1880-1933, giving a lowered growth rate of $36 \%$ for national income and $18 \%$ for national income per capita.

In 1965, the American Chinese scholars Liu Ta-chung and Yeh Kung-chia co-published the monograph The Economy of the Chinese Mainland: National Income and Economic Development 1933-1959, ${ }^{10}$ Which had a huge impact on Western scholarship. In this work, they reassessed the primary materials employed by Wu Pao-san and others (typically the Report on the Agricultural Situation, Land Utilization in China and the Census of Chinese Industry), and revised some of the measurement specifications prior to coming up with a new estimate of China's 1933 national income. They also expanded the research scope to include the earlier period of the People's Republic of China. Subsequently, they analyzed China's estimated GDP for 1931-1936, concluding that the Chinese economy was characterized by "mid-level industrial growth, agricultural stagnation and continuous expansion of population," with an annual per capita GDP growth rate of $0.33 \% .{ }^{11}$ In his report on the "Growth and Changing Structure of China's Twentieth Century"12 published in the 1970s, Dwight

8 For his calculations and results, see Chang Chung-li, The Income of the Gentry: Studies on Their Role in Nineteenth Century Chinese Society, Seattle: University of Washington Press,1962, pp. 291-325.

9 Feuerwerker's revised result was published in The Cambridge History of China: Late Qing. See John Fairbank and Liu Jingguang eds., The Cambridge History of China: Late Qing, Vol. 2, Trans. Institute of History, Chinese Academy of Social Sciences, Beijing: China Social Sciences Press, pp. 9-10.

10 Ta-chung Liu and Kung-chia Yeh, The Economy of the Chinese Mainland: National Income and Economic Development, 1933-1959, Princeton: Princeton University Press, 1965.

11 Kung-chia Yeh, "China's National Income, 1931-1936," in Hou Chi-ming and Yu Tzong-shian, eds., Modern Chinese Economic History, Taipei: The Institute of Economics, Academia Sinica, 1977, p. 120.

12 John K. Chang, Industrial Development in Pre-Communist China: A Quantitative Analysis, Chicago: Aldine, 
Perkins, a historian of the Chinese economy, not only revised Liu and Yeh's estimate of China's agricultural output in 1933, but also, based on his own research on Chinese agriculture and John K. Chang's research on Chinese industries, pushed the estimation back to 1914-1918, thereby establishing a new times series for GDP. His research showed that China's 1933 per capita GDP had only grown by an annual average rate of about $0.54 \%$ since $1914-1918$.

Other Western economists tried to tackle the second question. In 1981, French economist Paul Bairoch wrote "The Main Trends in National Economic Disparities since the Industrial Revolution," in which he used 1960 US dollars and prices to estimate China's GNP (Gross National Product) per capita for 1800, 1860, 1913, 1938, 1950, 1960, 1970, and 1977 in comparison with Western developed countries. He rebutted the ideas of Clark and Kuznets, arguing that China's per capita GDP before the Industrial Revolution was far higher than that of Western Europe. ${ }^{13}$ His research became well known when it was cited by French historian Fernand Braudel. ${ }^{14}$

In general, domestic and international discussion of these pioneer studies did not really kick off until the 1980s. The previous discussions, however, bore the marks of a new field of academic discontent. Firstl, Liu Dajun, Wu Pao-san, and a number of others laid out some basic methodologies for China's historical GDP that were used, changed and scrutinized in later debates. . According to the System of National Accounts (SNA), GDP statistics must comply with the "equivalence principle," under which GDP production, income, and expenditure are mutually equivalent. This indicates that GDP can be calculated by the associated production, income or expenditure approaches. These scholars also contributed in terms of the principles of indicators and the use of important indicator series to deduce historical GDP for other years. Their methods have commonly been regarded as canonical in studies of China's historical GDP, and were frequently cited and supplemented by latecomers such as Chang Chung-li, Liu Ta-chung, Feuerwerker, Perkins and Liu Ruizhong.

Second, almost all scholars viewed China as a whole in their analyses, and much of their research focused on GDP measurement for the Republic of China period, particularly in the 1930s. Starting from the 1950s, a major discussion emerged in mainland China over the origins of capitalism. Although the discussion barely touched on or addressed the issue of historical GDP, it did yield a large amount of quantitative material and historical data on Ming-Qing China from the angle of production and circulation. After the 1960s, scholars led by Xu Dixin and Wu Chengming undertook a research project on the "History of Capitalist Development in China." Their research estimated a set of quantitative indicators such as yield, output value, amount of trade and commodity prices, laying the groundwork for subsequent research on historical GDP.

Third, because these pioneer studies shared a common methodology, their period of focus was highly concentrated in the late Qing and Republican period, and the limited availability of data, these scholars tended to arrive at similar estimations during this period, which we already touched upon above. That is, they held that modern China's economic growth occurred concurrently with the development of modern industries during the Republic of China period. However, due to their tiny share of national GDP, modern industries played an insignificant role in spurring economic growth, so that this growth was nearly offset by stagnation in the rural sector; and before the advent of modern economic growth, the disparity in national income per capita between China and the West was very

1969.

13 Paul Bairoch, "The Main Trends in National Economic Disparities since the Industrial Revolution," in Paul Bairoch and Maurice Levy Leboyer, eds., Disparities in Economic Development since the Industrial Revolution, New York: St. Martin's Press, 1981, pp. 3-17.

14 Fernand Braudel, Civilisation matérielle, économie et capitalisme: XVe-XVIIIe siècle, trans. Shi Kangqiang et al., Beijing: SDX Publishing Company, 2002, pp. 617-618. 
slight.

\section{International Discussions and Emerging Trends: 1990-Present}

In the West, numerous efforts have been made to re-quantify the economic development level of different countries before the Industrial Revolution using GDP. This has led to the growing acceptance of the idea that substantial per capita economic growth did not begin with the Industrial Revolution in the $19^{\text {th }}$ century but with the late Middle Ages or the early modern period, when it was triggered by a sequence of important economic transformations. In other words, the "Malthusian trap", if it existed at all, could only be found in the period before the late Middle Ages. This new understanding was referred to by Jan de Vries as the "Revolt of the Early Modernists."15

Two economic historians figured prominently in Western research on China's historical GDP and were widely influential among Chinese scholars. One of them was American economic historian Thomas G. Rawski. In his China's Economic Growth before World War Two, published in 1989, Rawski used the latest data to revise the growth rates of GDP and per capita GDP during 1914-1918 and 1931-1936. He pegged the annual growth rate of China's per capita GDP at about $1.1 \%$, which was 0.77 percentage points higher than the results of Liu Ta-chung and others, and 0.56 percentage points higher than Perkins's. He argued that the pre-war Chinese economy was not as gloomy as had been previously assumed, but had fundamentally broken free from the traditional model of development and witnessed two decades of "modern economic growth." Such growth was almost comparable to that of Japan and its colonies. ${ }^{16}$

The other scholar was Angus Maddison, a British quantitative economic historian, who was the author of a.o. Monitoring the World Economy, 1880-1992; Chinese Economic Performance in the Long Run: 960-2030; The World Economy: A Millennial Perspective; The World Economy: Historical Statistics. In Maddison's view, for the first millennium AD, the Chinese economy did not achieve any substantial growth and its per capita GDP remained lower than Europe's. However, things began to change dramatically during the Northern and Southern Song dynasties in 960-1279, when China witnessed substantial economic growth and overtook Europe in terms of per capita GDP to become the largest and most developed economy in the world. In the following five and a half centuries, the Chinese economy declined again in per capita terms before Western Europe overtook it in the $14^{\text {th }}$ century. Nevertheless, till 1820, China's economic aggregate still amounted to a third of the world economic aggregate. Over the period from the Opium Wars to the First Sino-Japanese War of 1894-95, a sharp economic decline began to set in, but from 1890-1933, with the progress of industrialization in some places, the Chinese economy began to show continuous albeit slow growth. However, the outbreak of the Anti-Japanese War and the Liberation War again brought the per capita GDP in 1950 back to the pre-1890 level. ${ }^{17}$

An equally influential figure in this research field is the American historian Kenneth Pomeranz. In 2000, Pomeranz published The Great Divergence, arguing that until the $19^{\text {th }}$ century China's rich Yangtze region had been developing on par with England. Pomeranz saw two causes for the subsequent

15 Kuznets argued that over 15-20 years there was considerable growth in total output or per capita output which could be viewed as modern long-run economic growth. Simon Kuznets, Modern Economic Growth: Rate, Structure, and Spread, New Haven: Yale University Press, 1966, p. 27.

16 Thomas G. Rawski, Economic Growth in Prewar China, Oakland: University of California Press,1989.

17 See Angus Maddison, Monitoring the World Economy, 1820-1992, Paris: OECD Development Centre, 1995; Chinese Economic Performance in the Long Run, Paris: OECD Development Centre, 1998; The World Economy: A Millennial Perspective; and The World Economy: Historical Statistics. 
divergence between China and Europe: the opening up of the New World and the geographical advantage of British coal mines. Both factors contributed to the success of the Industrial Revolution in Britain and, hence, the "Great Divergence." 18 Pomeranz' ideas sparked a heated discussion in the international community. At first, scholars approached the issue in terms of agricultural productivity, property relations, family organization and even culture, focusing mostly on qualitative analysis. From 2004, the discussion became increasingly associated with research on China's historical GDP, leading to a gradual shift towards quantitative analysis and a "confluence" between the "great divergence" and historical GDP studies of the Chinese and Western economies from a comparative perspective. Before 2006, for instance, the separate session on the Great Divergence at the World Economic History Congress had basically no connection to historical GDP studies; but in the next three congresses, the relationship between the great divergence and historical GDP became a hot topic. Coupled with international discussion, research on China's historical GDP was pushed to the forefront, currently constituting one of the leading issues in international research on economic history.

In fact, almost all subsequent research on China's historical GDP at home and abroad has revolved around the challenges to the tradition posed by Rawski, Maddison and Pomeranz. First, their research threw new light on China's economic performance from the Opium Wars to the early Republican period. In 1995, scholars from Japan's Hitotsubashi University initiated the Asian Historical Statistics Project. After a re-estimation of China's GDP for eight years, they argued that the first phase of modern economic growth appeared in China around 1840-1911, earlier than Rawski et al. had assumed. ${ }^{19}$ On the basis of the materials previously employed by Wu Pao-san and Liu Ta-chung, the Chinese scholar Ma Debin gave a specific estimation of the GDP and per capita GDP of Jiangsu, Zhejiang and Shanghai in the 1930s. He found that per capita GDP in the lower reaches of the Yangtze River in 1933 was $60 \%$ higher than the average national level and 40\%-50\% higher than that of Korea and Northeast China, then under Japanese occupation; the region ranked third only to Japan and the Taiwan region. He believes that modern economic growth in the lower reaches of the Yangtze actually began in the early $20^{\text {th }}$ century rather than the $18^{\text {th }} .{ }^{20}$ Likewise, building on previous research, Ma Ye and Herman de Jong established a GDP time series for late Qing China (1840-1911), positing that the Chinese economy was in recession or stagnating during the period. This is consistent with Maddison's result, though it diverged from that of Hitotsubashi University. ${ }^{21}$ In a more recent study on the period 1661-1933 Xuyi et al, based on a large amount of primary and secondary sources, concluded that Chinese per capita GDP declined from the start of the Qing dynasty until the mid-19 ${ }^{\text {th }}$ century. In this respect they confirmed the findings of the Hitotsubashi scholars. Yet they also concluded growth during the Republican period was small. ${ }^{22}$

18 Kenneth Pomeranz, The Great Divergence: Europe, China, and the Making of the Modern World Economy, Princeton: Princeton University Press, 2000.

19 National Accounting Research Group, “An Analysis of Modern China's GDP Fluctuations,” in the Institute of Economic Research, Hitotsubashi University, Japan, ed., Proceedings of the International Symposium on the Economic Statistics of the Republic of China: Assessments and Estimations, Tokyo, 2000, pp. 213-222. The unpublished proceedings were compiled in a bilingual format; that is, all the papers have both Japanese and Chinese versions. In this study, we have quoted from the Chinese version.

20 Stephen Broadberry, Hanhui Guan and David Daokui Li, "China, Europe and the Great Divergence: A Study in Historical National Accounting," Proceedings of Asian Historical Economics Conference 2012, available at http://ahec2012.org/programme.html.

21 Ye Ma and Herman de Jong, "China's per capita GDP between 1840 and 1912: A New Estimation," Proceedings of Asian Historical Economics Conference 2012, available at http://ahec2012.org/programme.html. 22 Yi Xu, Zhihong Shi, Bas van Leeuwen, Yuping Ni, Zipeng Zhang, and Ye Ma, 'Chinese National Income, ca. 1661-1933', Australian Economic History Review (2016 forthcoming). 
Within China, discussion on this issue began with the publication of Modern China's Economic Development by Liu Foding, Wang Yuru and Yu Jianwei in 1997. According to Liu et al., the annual growth rate of per capita GDP was $-0.38 \%$ in $1850-1887,-2.87 \%$ in $1936-1949,0.30 \%$ in $1887-1914$, and $1.02 \%$ in 1914-1936, which comes very close to Rawski's estimate. ${ }^{23}$ In 50 Years of GDP Estimates and Economic Growth in Modern China: 1887-1936, Liu Wei and Chen Zhao substituted partial data series (e.g. import and export, population, modern industrial investment, etc.) in different macroeconomic models with a view to quantifying China's GDP in 1887-1930. Their study yielded a more optimistic rate of per capita GDP: $0.71 \%$ in $1887-1911,1.78 \%$ in $1911-1936$, and $1.25 \%$ in $1887-1936 .^{24}$

Second, the great divergence discussion has inspired new research on pre-modern China's economic development. This can be seen in two ways. One stream of research focuses on wages in pre-modern China. Recently, a number of scholars have begun to apply wages, along with production functions, to the calculate GDP and per capita GDP. Soon after the publication of The Great Divergence, Robert Allen et al. set out to collect data on wages, consumption and commodity prices in Europe and China. In a succession of articles, they challenged Pomeranz's views, arguing that although monetary wages in some big cities of $18^{\text {th }}$ century China were lower than those of England and the Low Countries, they were fairly close to those of central and southern Europe. It was not until the $20^{\text {th }}$ century that Europe as a whole began to surpass China in terms of living standards due to the steady growth of its backward regions, which began to surpass China, leaving living standards in big Chinese big cities only slightly higher than Europe's lowest level. ${ }^{25}$ The other stream relates directly to pre-modern China's GDP. In 2005, building on money supply, price levels and demographic data, Liu Guanglin applied the "Fisher equation" from monetary supply and demand theory to calculate per capita GDP over a number of years. He concluded that the per capita GDP of China in 1775 was slightly lower than that of Song China in $1120 .{ }^{26}$ Jan Luiten van Zanden combined the research on wages of Allen and others with the Cobb-Douglas production function previously used to calculate Europe's historical GDP and found that China's per capita GDP in the Yangtze region in 1750 was higher than the average European level but $15 \%$ lower than that of England at that time.

In 2010, two research monographs were published almost simultaneously in China as a response to studies of China's pre-modern GDP: The Economic Aggregate of Pre-modern China, 1600-1840: With a Discussion on Angus Maddison's Estimation of Ming and Qing China's GDP by Liu Ti, ${ }^{27}$ and The Early Modern Chinese economy: Examining the GDP of Huating and Lou Counties in the 1820s by Li Bozhong. ${ }^{28}$ Summarizing previous studies, Liu suggested that Maddison's use of data was

23 Liu Foding, Wang Yuru and Yu Jianwei, Modern China's Economic Development (近代中国的经济发展), Jinan: Shandong People's Publishing House, 1997.

24 Liu Wei and Chen Zhao, A 50-year Estimation of Modern China's GDP and Economic Growth: 1887-1936 (近代中国 50 年 GDP 的估算与经济增长研究: 1887-1936 年), Beijing: Economic Science Press, 2012.

25 See Robert C. Allen, "The Great Divergence in European Wages and Prices from the Middle Ages to the First World War," Explorations in Economic History, vol. 38, no. 4, 2001, pp. 411-447; Robert C. Allen, J.P. Bassino, Debin Ma, C. Moll-Murata and J.L. van Zandan, "Wages, Prices and Living Standards in China, 1738-1925: In Comparison with Europe, Japan and India," Economic Historical Review, vol. 64, S1, 2011, pp. 8-38.

26 Guanglin Liu, Wrestling for Power: The State and the Economy in Later Imperial China, 1000-1700, Doctoral Dissertation, Cambridge: Harvard University Press, 2005. Also see his paper in Chinese: "A Tentative Study of National Income Changes during the Song and Ming Dynasties” (宋明间国民收入长期变动之蟙测), Journal of Tsinghua University (清华大学学报), 2009, no. 3.

27 Liu Ti, The Economic Aggregate of Pre-modern China in 1600-1840: With a Discussion of Angus Maddison's Estimation of Ming and Qing China's GDP (前近代中国总量经济研究（1600-1840）：兼论安格斯・麦迪森对 明清 GDP 的估算), Shanghai: Shanghai Century Publishing Group, 2010.

$28 \mathrm{Li}$ Bozhong, The Early Modern Chinese Economy: Examining the GDP of Huating and Lou Counties in the $1820 s$ (中国的早期近代经济: 1820 年代华亭一娄县地区 GDP 研究), Beijing: Zhonghua Book Company, 2010. 
seriously defective. ${ }^{29}$ The same applied to $\mathrm{Li}$ who argued that urbanization had already been accomplished in the Huating and Lou counties in Songjiang Prefecture by the early $19^{\text {th }}$ century. He further compared the GDP of the two counties in the 1820s with that of the Netherlands in the early $19^{\text {th }}$ century, and concluded that "the Yangtze region in the early $19^{\text {th }}$ century was no longer a traditional agriculture-based economy, but rather an early modern economy based on business and commerce." Later, in a collaborative work with Jan Luiten van Zanden, he argued that the per capita GDP of Huating and Lou counties in the 1820s was $86 \%$ lower than that of the Netherlands during the same period.

In the same year, Guan Hanhui and David Daokui Li co-published A Study of GDP and Its Structure in China's Ming Dynasty. In their work, Guan and Li made use of numerous secondary sources and previous estimations to calculate the GDP in Ming China. They found that overall, Ming economic growth was not fast, with an annual GDP growth rate averaging $0.29 \%$; and that although there was some growth in the size of national economy, the annual per capita income did not show noticeable changes and remained around an average level of 6 hectoliters of wheat. ${ }^{30}$ More recently, the authors cooperated with Stephen Broadberry on a project reconstructing a GDP time-series from the Northern Song to the Qing dynasty (1850), arguing that per capita GDP in the Northern Song was 1.46 times that in the Ming and 1.89 times that in the Qing. Northern Song had been substantially richer than Britain in terms of per capita wealth in 1086, and it was only overtaken by Britain in 1400 . Therefore, the "Great Divergence" between northwestern Europe and China appeared in 1500 rather than in $1800 .{ }^{31}$

Confronted with an abundance of new research on pre-modern China's GDP, Kenneth Pomeranz, the forefather of the "Great Divergence," partially accepted Li Bozhong and Jan Luiten van Zanden's ideas; i.e. in terms of economic development, $18^{\text {th }}$-century England and the Low Countries in northwestern Europe were more advanced than China's most developed region, the Yangtze region. ${ }^{32}$

\section{From Exchanges of Ideas to Theoretical Reflection: A Shift in Historical GDP Research}

The heated in-depth international discussions since the 1990s have prompted the emergence of some new trends in China's historical GDP research. First, in terms of research methodology, scholars no longer resort to the classical method established by Wu Pao-san et al., but have introduced a variety of modern macro-economic models in accordance with the characteristics of the research materials for the particular period under study, giving rise to a diversification of research methodologies. Of these, Robert Allen's use of real wages, Jan Luiten van Zanden's use of the Cobb-Douglas production function, Liu Guanglin's use of the Fisher equation and Liu Wei's use of the aggregate supply-demand model and the import-export model are all significant steps.

29 The book also contains some basic ideas expressed in his previous research. See Liu Ti, "An Estimation of China's GDP in 1600-1840” (1600-1840 年中国国内生产总值的估算), Economic Research Journal (经济研究), 2009, no. 10; “A Discussion of Angus Maddison’s Estimates of Pre-Modern China’s GDP” (论安格斯・麦迪森对 前近代中国 GDP 的估算), The Qing History Journal (清史研究), 2010, no. 5.

30 Hanhui Guan and David Daokui Li, “A Study of GDP and Its Structure in China's Ming Dynasty” (明代 GDP 及结构试探), China Economic Quarterly (经济学), 2010, no. 3.

31 Stephen Broadberry, Hanhui Guan and David Daokui Li, "China, Europe and the Great Divergence: A Study in Historical National Accounting," Proceedings of Asian Historical Economics Conference 2012, available at http://ahec2012.org/programme.html.

32 Kenneth Pomeranz, "Ten Years After: Responses and Reconsiderations," Historically Speaking, vol. 12, 2011, no. 4, pp. 20-25. 
Second, in terms of research subject, as a result of the two major discussions, scholars have begun to turn their attention from China in general to the inland area, notably the Yangtze region. In terms of time, scholars no longer focus solely on the 1930s, but have begun to set their sights on the period of the Anti-Japanese war, the first decade of the $20^{\text {th }}$ century, the second half of the $19^{\text {th }}$ century, and even the later Chinese empire after the Song.

Third, data collection and arrangement have also seen considerable progress. From as early as the $12^{\text {th }}$ century to as late as the $1940 \mathrm{~s}$, domestic and international scholars are gathering historical data. In some sectors and some areas, data collection during the current period has surpassed all previous periods in quality and quantity.

Last, there have been sharply divergent opinions among scholars on the estimates produced by the two international discussions. Although, after 1937, there was a consensus on modern China's negative economic growth, scholars differ sharply on the growth rate in the late Qing and the first three decades of the Republic of China. The discussion of Pomeranz' "Great Divergence" between China and the West inclined scholars to believe that in the $18^{\text {th }}$ and $19^{\text {th }}$ centuries, China had already fallen behind Western Europe in terms of per capita GDP at both the local and the national level. Nevertheless, there is still much dispute over exactly when this divergence occurred, as can be seen from the views ascribing it to the Song, the Ming, the mid-Qing, and so forth.

In the midst of the heated debate on historical GDP estimates, there have also been some voices calling for a theoretical reflection on these issues. This shift toward reflection began with the opening of the "Symposium on Data Sources and Methodologies of GDP Estimation in the Economic History of China" organized by the Editorial Department of Researches in Chinese Economic History in 2011. The participants' views coalesced around two approaches. The first view criticized many scholars' current practice of relying extensively on secondary data from previous studies while neglecting the collection and organization of original data, urging instead a "profound and exhaustive survey" of historical materials with a view to "reconstructing historical data." On that basis, these scholars advocated applying the income method to calculating the national economic aggregate. Some even proposed building databases of original and revised data on the economy from the Opium Wars on, so as to modify previous studies of China's historical GDP for this period. Others held that as historical data on China are not statistically significant, scholars should follow in the steps of Li Bozhong's study of Huating and Lou counties rather than seeking to be comprehensive and exhaustive.

The second view gave a specific assessment of the methodologies used in historical GDP studies. Some scholars argued that using cross-sectional average prices to calculate cross-regional GDP tends to result in an overestimation of the economic aggregate; using the annual average price without taking the seasonal factor into account tends to distort the estimation of GDP structure; and when GDP is used for international comparisons, current purchasing power parity is a more applicable method. Others held that we should not put the cart before the horse and use theoretical models to arrive at macro-level conclusions and thence deduce micro-interpretations; rather, to estimate China's GDP from the Opium Wars on, we should ensure that the premises of a theoretical function are consistent with the macro-economic operational environment and that the settings of causal relationships are reasonable. Only in this way will we get significant results from quantitative models. ${ }^{33}$

In the wake of the symposium, a growing sense of theoretical reflection has appeared among Chinese scholars. In "GDP Research Pitfalls in Chinese Economic History,” for instance, Du Xuncheng

33 Both views are detailed in "Conversations in Writing on GDP Calculation in Chinese Economic History" (中 国经济史 GDP 估算研究笔谈), Researches in Chinese Economic History (中国经济史研究), 2011, nos. 3 and 4. 
and Li Jin argued that the existing GDP historical studies are distorted and deviate from the standard definition of GDP. ${ }^{34} \mathrm{Du}$ subsequently used the total circulation of domestic commodities to re-calculate China's GDP in 1933 within a range of total market values, and obtained a 30\% lower result than that of Wu Pao-san et al. ${ }^{35}$ Chen Zhengping maintains that research on GDP from the 1840s to the Republican era should be split into two parts, market and non-market. He also emphasizes the need to study the GDC (Gross Domestic Commodity Economy) to highlight the dualism of the Chinese economy, with a view to measuring the development of China's commodity economy and analyzing the changes in its dual economy over this period. ${ }^{36}$

However, the scholars represented by Shi Zhihong have different views. They argue that European countries also underwent a major change in their dualistic economic structure from early modern times to the late Middle Ages, posing a similar problem of having to deal with an existing market and non-market economyfor those Western scholars who apply GDP calculation methods to the study of European economic history. It was precisely for this reason that they put forward a new "System of Historical National Accounts" specifically designed for calculating European economic growth before the Industrial Revolution, and developed a new set of historical statistical methods that differed from those used in the modern System of National Accounts. The new methods explicitly include both market and non-market activities in the rural and handicraft sectors of GDP, but exclude the non-market part of the service industry. ${ }^{37}$ The scope of the standard definition of GDP, as extended by contemporary economists to meet the practical needs of the dualistic economy of developing countries, is almost equivalent in both content and range of application to the Historical National Accounts proposed by economic historians to calculate economic growth before the $19^{\text {th }}$ century. What they have in common is that both advocate the inclusion of non-market activities. We believe that the debate about whether the system of GDP calculation stemming from the standard definition of GDP can be applied to historical studies will be replaced by discussion of how non-market activities can be calculated and how the extent of economic dualism can be quantified. ${ }^{38}$

Soon after Li Bozhong's work was published, Peng Kaixiang pointed out that Li's assessment of living standards on the basis of food consumption or nutrition intake was defective; his use of GDP as the main measure of Huating and Lou counties' developmental level was biased; his assumption of an incomplete labor market was inconsistent with his conclusion of full employment; and there was room for discussion with respect to whether the two counties had fully realized "Smithian growth." $39 \mathrm{Ni}$ Yuping also wrote articles responding to Li Bozhong and Liu Ti's research. Appraising Li's study as being "integrated into the world," he argued that Li had made an exhaustive survey of historical

34 Du Xuncheng and Li Jin, “ GDP Research Pitfalls in Chinese Economic History” (中国经济史 “GDP” 研究之 误区), Academic Monthly (学术月刊), 2011, no. 10.

35 See Du Xuncheng, “The Definition of 'Market' and the Estimation of China's 1933 GDP” (市场的定义与 1933 年 GDP 测算), Journal of Social Sciences (社会科学), 2013, no. 1.

36 See Chen Zhengping, “A Statistical Study of the Chinese Economy from the Opium Wars On” (近代中国经济 统计研究), Research Proposal for the NSSFC Key Program (国家社科基金重大项目开题报告), available at http://blog.sina.com.cn/s/blog_aeff03e5010173tn.html.

37 The pioneering contribution to research on the System of Historical National Accounts was made by Jan Luiten van Zanden and his team. For the concept and its methodology, see Jan-Pieter Smits, Edwin Holings and Jan Luiten van Zanden, Dutch GNP and Its Components, 1800-1913, Groningen Growth and Development Centre, pp. 5-7. For the application of the new system by British scholars, see Stephen Broadberry, Bruce Campbell, Alexander Klein, Mark Overton and Bas van Leeuwen, British Economic Growth, 1270-1870 (unpublished).

38 See Shi Zhihong, Xu Yi and Ni Yuping, "An Estimation of China's Economic Aggregate in the Mid-19 Century” (19 世纪中期的中国经济总量估值), unpublished.

39 Peng Kaixiang, “A Three-dimensional Perspective on Economic Tension in Traditional China” (传统中国经 济张力的立体透视), Economic Research Journal (经济研究), 2011, no. 5. 
materials and showed a broad vision in highlighting general history and international comparisons. ${ }^{40}$ At the same time, he criticized Liu's study for being based solely on "secondary materials and existing research," saying that he had made commonsense mistakes in interpreting historical documentation, and had obviously adopted a utilitarian attitude toward data, regardless of the historical truth and rationality underlying those data. This invalidated his conclusions. ${ }^{41}$

\section{Thoughts on the Future of China's Historical GDP Research}

After nearly a hundred years of development, China's historical GDP research still enjoys bright prospects. It serves as a nexus between historiography and economics, as well as a bridge for mutual understanding between China and the rest of the world. We believe that future research on China's historical GDP should attempt to address the following areas.

\section{Estimation methods}

What have prompted the international debate are the different results stemming from different research methods and sources. Since the 1990s, a wide variety of economic models in China's historical GDP studies have been introduced and experimented with. In this connection, an unprecedentedly large quantity of historical data has been assembled and developed. Similarly, more recent theoretical reflection has unfolded around the issues of materials and methods. All these demonstrate the growing maturity and sophistication of the field.

So far, the methodology most widely recognized by domestic and international scholars has been the classic one established by Wu Pao-san et al., in which GDP is calculated by way of production, income and expenditure; this method has been applied to about $70 \%$ of all studies. However, due to variations in basic data and methodological limitations, even scholars using the same method may get different results. Here, we argue that apart from the classic method, a diversity of methods should be encouraged in GDP calculation so that the results of the estimations can be cross-checked against each other. In fact, Wu himself used the production method to calculate China's 1933 GDP and used the result of the expenditure method to verify it. Later, there was a view that given China's historical reality, we should use the production method to measure the output value of agriculture, handicrafts and industry, use the income method to measure the output value of the service industry, and use the expenditure method for verification purposes. Here, we argue that cross-checking should be applied to the verification of both the estimated GDP result and the whole process of calculation; that is, we should try to cross-check all indicators relating to GDP calculation. For instance, after finding the cultivated land area in a historical period, we can check it using historical materials and data on climate change at the time; and after calculating the production or output value of a particular industry or sector, we can use per capita consumption, real wages, imports and exports, currency circulation, material inputs, labor force and labor productivity, along with the relevant economic models, to verify the estimated results. Cross-checking will usually allow us to redress the errors incurred by the use of a single method and will enhance the precision of estimation.

\section{Basic data}

China's historical GDP research took off at almost the same time as the West's. Later, however, it

40 Ni Yuping, “Integrated into the World: A Review of Li Bozhong's Early Modern Chinese Economy” (一部 “ 融入世界” 的著作——评李伯重《中国的早期近代经济》), Researches in Chinese Economic History (中国经 济史研究), 2011, no. 1 .

41 Ni Yuping, “A Review of The Economic Aggregate of Pre-modern China in 1600-1840” (评《前近代中国总 量经济研究 (1600-1840) 》), Journal of Chinese Historical Studies (中国史研究), 2013, no. 1. 
began to fall behind in both depth and breadth. The major reason for this lies in the remarkable progress made by the West in data collection. As early as the mid-19 $9^{\text {th }}$ century, massive data collection and organization was under way in Western countries, though much of the effort focused on price, wage, and industrial data. After Kuznets et al. established the System of National Accounts, economists began to join hands with economic historians in assembling and collecting historical data in accordance with the SNA framework. Therefore, Western studies of historical GDP came as a natural result of historical data collection. In China, however, it was not until the late Qing and the early Republican period that modern Western statistical methods were adopted to compile and record economic activities. Wu Pao-san et al.'s estimate of China's national income in 1933 was made during this period. However, despite the continuous efforts of scholars such as Wu Pao-san, Chang Chung-li, Dwight Perkins, Liu Ta-chung, Wu Chengming, and Thomas Rawski on historical GDP, basic data compilation leaves something to be desired when it comes to a careful calculation of historical GDP during the Qing and the Republican period. In general, post-1840 data compilation is slighter better than for the pre-1840 period. In the fields where most effort has been concentrated, such as demographic change across dynasties, agriculture, finance and currency, domestic and international trade, government revenues, wages, and modern industries. However, there still is much dispute over statistics, and this tends to affect the estimated results of historical GDP. In many other fields such as prices, and the handicraftand service industry, little systematic data mining and compilation has been carried out, due to the dispersal and fragmentation of data and materials.

Over the past decade, the insufficiency of basic data has resulted in divergent opinions on China's historical GDP. As primary sources usually cluster in the field of wages, personal income and money supply, some scholars have turned to these fields and derived historical GDP by using macro-economic models; others continue to draw on previous research and secondary sources, and use the production and expenditure methods of Wu Pao-san et al. to calculate historical GDP; only a few start from primary historical sources and provide an independent estimation of historical GDP based on a full and exhaustive investigation of original data. For these reasons, and given the fact that basic data compilation lags far behind historical GDP research, a large number of low-level and redundant studies have appeared under the guise of "quantitative models," severely affecting innovation in this field. Therefore, at the present stage, scholars engaged in research on China's historical GDP should focus on large-scale reconstruction of historical data. In controversial fields, it is necessary to make a careful comparison of the differences among previous estimations and statistics and to continue to expand statistical scope and sample size so as to reduce controversy. In the weaker fields of historical data collection, it is necessary to start with local documentation such as local gazetteers, local archives, documents and contracts, family lineages and stele inscriptions, and travel notes, as well as special surveys of particular fields in particular places since the nineteenth century, so that as many samples as possible can be collected and local samples can be used to deduce national statistics in historical GDP calculation.

Of course, in reconstructing basic historical data, we should not only take pains to collect, compile and authenticate original data, but should also "infer from" and "estimate" the data in a reasonable way. Generally, such basic data fall into two types. The first refers to the national statistical data released by the central government, including population, cultivated land, revenues and the production and output value of given industries. These data simply constitute the indicators for central government taxation; they do not reflect the reality of the country's economic activities. They must be used together with other materials so that "taxation quantities" can be converted into "real quantities." The other type 
includes a great variety of economic indicators that reflect economic changes in a given area as documented in materials such as local gazetteers, collected essays and local surveys. However, as these records are kept in varying degrees of detail, and tend to be ridden with vague descriptions of "thousands and thousands," "an enormous amount," "a huge amount of money," "all the households practice weaving," "no less than ten thousand households," or "producing as much ten thousand pi a day of silk," they must be checked against other sources, so that these "empty figures" can be given substance. In the process of reconstructing different kinds of data, scholars' varying understandings of the economic development level of a historical period and their different uses of original materials may lead them to different or even totally divergent conclusions. Again, we argue that a variety of cross-checking methods should be used as much as possible to enhance the quality of our reconstruction of historical data.

\section{Historical GDP studies and international comparisons}

An important reason for the widespread attention to China's historical GDP research lies in international comparisons. As Wu Chengming put it, "In economic history studies, quantitative analysis should be applied wherever possible. Qualitative analysis only provides a way of conceptualizing things; it must be used in combination with quantitative analysis to provide specific information and sometimes to rectify the errors in quantitative analysis." Much of the existing research on economic history focuses on the relations of production, which are, however, highly specific for different countries and therefore cannot be compared. Although GDP calculation varies greatly with different scholars, it still serves as an important composite indicator that encompasses economic aggregate and economic structure. Through the indicator of GDP, we can gain a general view of a country's economic development level, economic fluctuations and structural changes within a given historical period, making longitudinal and cross-sectional comparisons convenient. It is precisely the research on historical GDP that makes possible unified criteria and widely accepted conclusions in the ongoing domestic and international debate over whether the Chinese economy was stagnant or progressing during the Ming, Qing and Republican era, and it is only this research that gives international discussion of the Great Divergence a good platform for interchange.

The ultimate goal of historical GDP research consists of international comparisons. William Petty compared the national wealth of Britain, the Netherlands and France, and Bairoch and Maddison's research was also conducted for the purpose of international comparisons. For a variety of reasons, the GDP research system that has its origins in the West still, to a large extent, takes "European experience" and modern Europe's economic development as the most important or even the sole criterion. We should be fully aware of this without either totally repudiating it or being limited by it. The progress of history is never linear; nor is it simply a matter of functional relations. Quantitative research is an analytical instrument. Though it helps academic development, quantitative research on its own or undertaken for its own sake can only lead scientific research astray. As Chinese scholars, we should focus more on research on the structure, characteristics and laws of Chinese economic operations and integrate them into the global economic system, so as to examine the development of the Chinese economy and its interrelationship with Western economies. Only in this way can we "endow the international comparisons of China's historical GDP calculation and economic aggregate with Chinese characteristics, and make our distinctive contribution to the study of 'holistic' world economic history, rather than relegating it to a quantitative interpretation of the new version of 'Eurocentrism.',

In sum, the sound development of China's historical GDP research hinges critically on a proper 
handling of the above-mentioned three issues, especially the question of sources. Reconstructing a systematic, massive and reliable database of historical data is a crucial task for China's GDP research in the years to come. Since its very inception, China's historical GDP research has been characterized by Sino-Western exchanges, mutual stimulus and joint development. In this research movement, Chinese scholars can play a greater role. We are strongly convinced that Chinese scholars, hard-working and dedicated as they are, will blaze a new trail for historical GDP research that accords with the laws of economic development. Importantly, this will also pave the way for Chinese scholarship to become integrated into the international community.

\section{Notes on Contributors}

Ni Yuping, Ph.D in history, is Professor and Doctoral Supervisor at the School of Humanities, Tsinghua University. His field of research is the social and economic history of the Qing dynasty. To date, he has published over 50 monographs and articles. Some of his representative works are Tribute Grain Transport and Social Change in Qing China (清代漕粮海运与社会变迁, Shanghai: Shanghai Bookstore Publishing House, 2005); Finance and Society in the Qing Dynasty: From Jiaqing to Daoguang (清朝嘉道财政与社会, Beijing: The Commercial Press, 2013); etc. E-mail:niyuping@ sina.com.

$\mathrm{Xu}$ Yi obtained his doctorate in economics from the Graduate School of the Chinese Academy of Social Sciences in 2007. Currently, he is Professor at the College of Historical Culture and Tourism, Guangxi Normal University. His fields of interest are quantitative economic history and borderland history. He has published over 20 academic articles and 3 monographs. Some of his representative publications are The Taxation System in Jiangsu Province: 1853-1911 (Shanghai: Shanghai University of Finance and Economics Press, 2009); The Qing Empire's Acculturation Strategies in Guangxi (Beijing: Social Sciences Academic Press, 2013); “An Overview of Late Qing Tariffs and Taxation: 1851-7894” (晚清捐税综论—— 1851-1894 年为背景, Researches in Chinese Economic History [中国经济史研究], 2009, no. 3); “The Performance of Chinese Industry in a World Perspective, ca. 1850-2012: A Value Added Approach” (中国工业的长期表现及其全球比较: 1850-2012 年一一以增加值核算为 中心, Researches in Chinese Economic History, 2016, no. 1); “The Spread of Culture and Education and Borderland Social Order: Early Qing Cultural and Educational Governance of the Fujiang River Basin” (文教普及 与边疆秩序——清前期对广西府江流域的文教治理, China's Borderland History and Geography Studies [中国 边疆史地研究], 2010, no. 3); etc. E-mail: xuyi1840@163.com.

Bas van Leeuwen received his doctor's degree in 2007 from Utrecht University, the Netherlands. He is currently Senior Fellow at the Netherlands International Institute of Social History. His areas of interest are world economic history, Southeast Asian history, and the comparative economic history of China and the West. His publications include a.o. British Economic Growth, 1270-1870 (Cambridge: Cambridge University Press, 2015); "Educational and Income Inequality in Europe, ca. 1870-2000" (Cliometrica, vol. 8, 2014, no. 3); "When Did Britain Industrialise? The Sectoral Distribution of the Labour Force and Labour Productivity in Britain, 1381-1851" (Explorations in Economic History, vol. 50, 2003, no. 1); "Persistent but Not Consistent: The Growth of National Income in Holland 1347-1807" (Explorations in Economic History, vol. 49, 2012, no. 2). E-mail: bas.vanleeuwen1@gmail.com.

\section{References}


Revised by Sally Borthwick 